\title{
Overview of fluoride distribution in major aquifer units of northern Nigeria
}

\author{
Hyeladi U. Dibal ${ }^{1 *}$, Kryzstoff Schoeneich $^{2}$, Ibrahim Garba ${ }^{3}$, U. A. Lar ${ }^{1}$, E. A. Bala ${ }^{2}$ \\ ${ }^{1}$ Department of Geology and Mining, University of Jos, Jos, Nigeria; \\ *Corresponding Author: dibalu@unijos.edu.ng \\ ${ }^{2}$ Department of Geology, Ahmadu Bello University Zaria, Zaria, Nigeria \\ ${ }^{3}$ Kano State University of Science and Technology Wudil, Kano, Nigeria
}

Received 11 October 2012; revised 18 November 2012; accepted 24 November 2012

\section{ABSTRACT}

Symptoms of dental fluorosis such as mottled teeth are common among adults, youth and children in several rural communities in northern Nigeria. This has inspired the Authors to investigate the concentration of fluoride in the natural water systems of the major aquifer units (Basement, Sedimentary, Volcanic and Younger Granites) in some parts of northern Nigeria and to delineate areas of high risk of dental fluorosis, crippling skeletal fluorosis and dental caries. Six hundred and twenty seven analytical values for water were obtained from the literature and from analysis of samples from the major aquifer units of northern Nigeria: Basement-232, Sedimentary-328, Younger Granites-38 and Volcanic-28. Fluoride concentrations range from 0.03 to $\mathbf{1 0 . 3 0}$ $\mathrm{mg} / \mathrm{L}$ in the Basement Aquifer; 0.00 to $5.00 \mathrm{mg} / \mathrm{L}$ in the Sedimentary Aquifer; 0.00 to $0.89 \mathrm{mg} / \mathrm{L}$ in the Younger Granites Aquifer; and 0.00 to 0.78 $\mathrm{mg} / \mathrm{L}$ in the Volcanic Aquifer. A background value of $1.0 \mathrm{mg} / \mathrm{L}$ for fluoride concentration for northern Nigeria has been determined in this study. Areas identified with high fluoride in their waters above the World Health Organisation (WHO) recommended maximum permissible level in drinking water of $1.5 \mathrm{mg} / \mathrm{L}$ are: Dzuma, Dilchidima, Ngalbi, Udin, Kaltungo Biliri, Shongwom, Dass in the the northeast basement aquifers; Maiduguri, Mafa, Mobbar, Ngala, Logomani, Gombe in the northeast sedimentary aquifers: Langtang, Dorong, Furzi in the northcentral basement aquifers and Pakoro in the northcentral sedimentary aquifers: Shawo and Barkin Lamba in the northwest basement aquifers. No anomalously high values of fluoride were recorded in the northwest sedimentary aquifers. All waters sampled in the Younger Granites and the Volcanic Aquifers have fluoride contents lower than the WHO recommended maximum permissible level in drinking water of $1.5 \mathrm{mg} / \mathrm{L}$; and over ninety percent of the waters have fluoride concentration below the $0.5 \mathrm{mg} / \mathrm{L}$ recommended by WHO for the prevention of dental caries. Positive correlation between dental fluorosis and high fluoride water consumption has been established in all the areas with high fluoride in their waters. Positive correlation has also been established between genu valgum (bowing of legs) and consumption of high fluoride waters in Langtang Area. These data have been used to delineate areas of the Younger Granites Province and the Volcanic Province where inhabitants are at high risk of having dental caries.

Keywords: Fluoride Distribution; Major Aquifer Units; Northern Nigeria

\section{INTRODUCTION}

Fluoride is distributed worldwide in water. However, dietary sources are considered to play significant roles in the tropical areas where fluoride levels do not correlate with urinary or serum levels [1].

Fluorosis has been reported as one of the main endemics in the world by [2,3]. It is caused by taking excess fluoride in water, foods and tea. Water-rock interactions including the process of dissolution/precipitation, adsorption/ desorption and dilution/condensation directly influence the fluoride content of groundwater [4].

Fluoride could either be beneficial or detrimental to human and animals, depending on the levels it is consumed in water and foods. Low levels of fluoride in water $(<0.75 \mathrm{mg} / \mathrm{L})$ may result in the development of dental caries and higher levels $(>1.5 \mathrm{mg} / \mathrm{L})$ may result in mottled teeth (dental fluorosis) in children less than 7 years of age. Skeletal fluorosis, low IQ, reduced immunity and 
hip fracture in women [5,6]. Fluoride has been accepted generally to stimulate bone formation according to [7] and when consumed in optimal concentration it has beneficial effects on the teeth by hardening the enamel and reduces the incidence of dental caries [8].

Cases of dental fluorosis have been reported in many parts of Northern Nigeria (Bauchi, Gombe, Adamawa, Plateau, and Benue) [9-11]. Dental fluorosis or otherwise mottled teeth in several rural communities in Nigeria has been linked to many causes among which is; excess consumption of honey by a pregnant mother which lead to a child being born with dental fluorosis, This has inspired the authors to investigate the distribution of fluoride in the natural water systems of the major aquifer units of Northern Nigeria and its possible health implications.

\section{GEOLOGY AND HYDROGEOLOGY OF NORTHERN NIGERIA}

\subsection{Geology and Hydrogeology of the Basement Rocks}

The hydrogeology of Northern Nigeria reflects it's on geology categorized into the crystalline basement com- plex area and the sedimentary basins [12]. The basement complex area is further subdivided into;

- The Older Granite, Migmatite and Gneiss complex area.

- The Metasediments, Quartzite and Schists complex area.

- The Younger Granite/Volcanic area.

Over $50 \%$ of northern Nigeria is covered by both the rocks of the basement complex rock types and the sedimentary rocks (Figure 1).

The Older Granites, migmatite and gneissic rocks comprise the extensive mass of metamorphic rocks underlying most areas of the north and west of the country. The rocks include different textures of granites; coarse to fine consisting essentially of biotite, feldspar quartz, which are indications of the hydrogeological characteristics. While the coarse granites weather into water bearing sandy residue, the syenitic rock types, with the predominance of the unstable minerals e.g. feldspars, decompose into plastic or soft clays and other argillites which behave only as aquitards or aquicludes.

Generally only small amount of water can be obtained

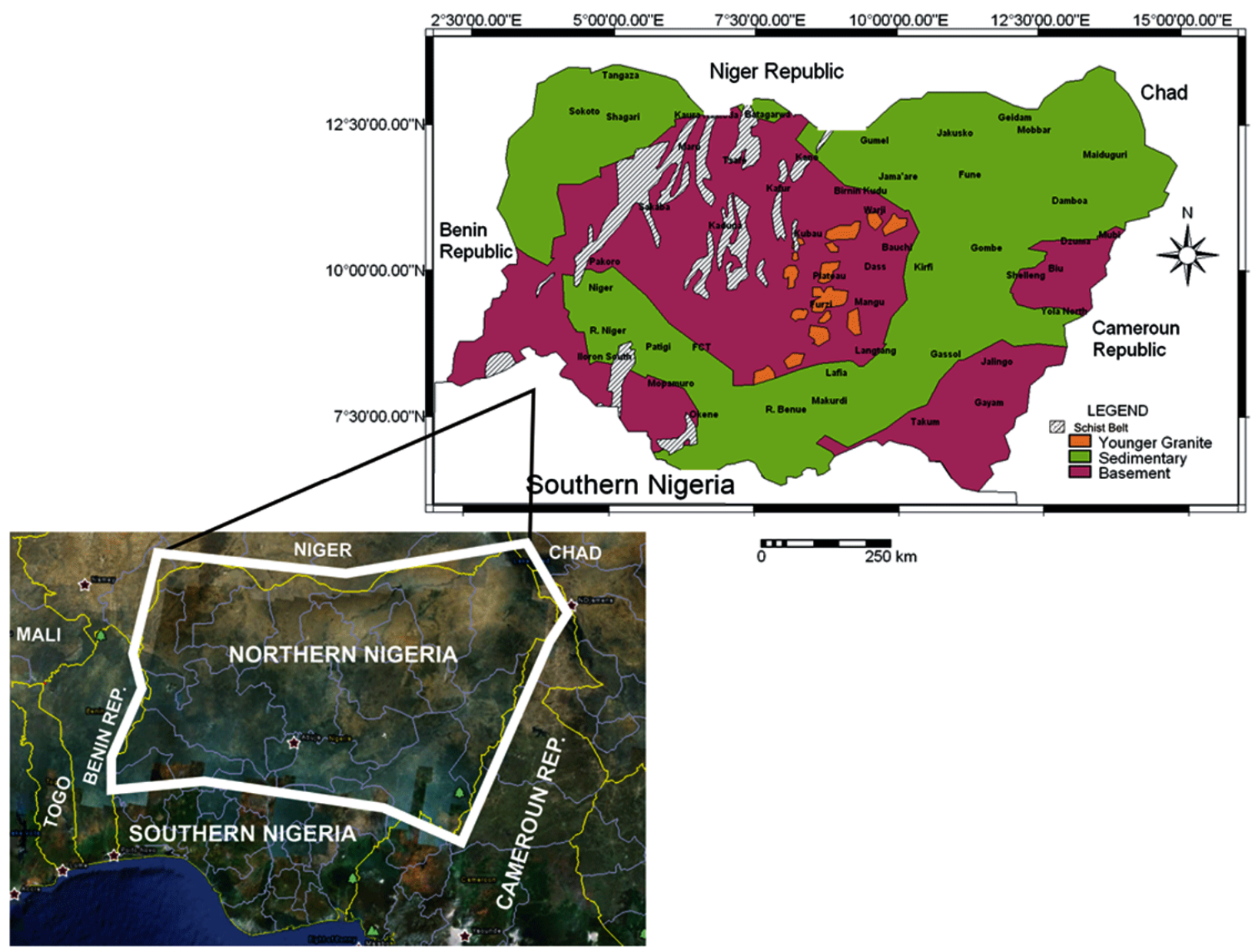

Figure 1. Location map and simplified geologic map of northern Nigeria. 
in the freshly unweathered bedrock below the weathered layers. Even when fractured, the clayey materials tend to seal the openings of the fractures and prevent water from being transmitted into boreholes. The meta-sedimentary areas, often grade into the surrounding country rock which invariably are the Older Granites series and hence difficult to distinguish them according to [12]. The hydrogeological properties depend on the texture of the meta-sediments hence the schists and the phyllites are poor aquifers, while the quartzites and pegmatites may present good aquifers where, fractured

\subsection{Geology and Hydrogeology of the Younger Granites and the Volcanic Rocks}

The Younger Granites complex areas comprise series of high level intrusive granites of different chemical composition, within the Basement Complex. The granitic series include alkali feldspar granites associated with rhyolites and minor gabbros and syenites. The emplacement of the rocks is preceded by a series of volcanic activities which is responsible for its peculiar geomorphologic and textural set up. Of hydrogeological importance are those deeply dissected fractures within the rock formations, which rise above the Plateau. Three aquifers exist in the Younger Granites/Fluvio Volcanic Province; the fractured crystalline aquifer, soft overburden and volcanic aquifer [13]. The fractured aquifer contains water in amounts on which open wells and sometimes boreholes can be sited in tectonically fractured zones.

The soft overburden aquifer consists predominant of clay and insitu chemically weathered rocks. Lithologically, it is highly variable. The most common constituents are sands and gritty clays formed as a result of burrowing activities of termites. This makes the soft overburden aquifer lack natural filtration.

\subsection{Hydrogeology of the Sedimentary Basins}

The sedimentary aquifers are considered according to the hydrogeological basins categorized into the Chad Basin, Sokoto Basin, Benue Basin and the Niger Basin.

\subsection{Chad Basin}

The Chad Basin includes the Hadejia-Yobe Basin and the East Chad Basin. The basin area spreads out from the northeastern corner of Nigeria into the southern fringes of the Sahara Desert in Niger, Cameroun and Sudan. The Nigerian part of the basin consists of only about one third of the whole basin. There are three layers of aquifers, the Upper Water Table Aquifer, the Middle Zone Aquifer and Lower Artesian Aquifer.

\subsection{Sokoto Basin}

The Sokoto Basin like the Chad Basin is a part of Nigeria's second international basin also called the lllumeden Basin. The aquiferous units are: Gundumi and lllo Formations constituting about $30 \%$ of the basin [14]. Like the Chad Basin, aquifers found in the Gundumi/Illo Formation are water table, semi confined and artesian aquifers. Other aquiferous units are Taloka, Wurno, Kalambaina and Gwandu Formations. The Dange and Dukamaje Formations are entirely aquiclude and aquitard.

\subsection{Benue Basin}

The Benue Basin is a continuous elongated geological structure, conveniently subdivided into three basins described as Upper. Middle and Lower Benue Basins. Hydrogeologically, separation into these basins may not be possible since the basin is seen as one extended complex hydrogeological structure comprising a number of isolated or aquiferous units within predominantly semi permeable to impermeable geological formations [12]. The Upper Benue Basin is separated from the Chad Basin by the Zambuk Ridge, which stretches in a NE-SW, running from Zambuk to the Biu Plateau. Two potential groundwater basin have been demarcated in the Upper Benue Basin [12] the Gombe to the north and the Lau to the south separated by the Lamurde Anticline. The sub basins contain aquiferous formations, which include the Bima, Sandstones, Yolde, Pindiga and the Gulani Sandstones. Extensive deposits of the Bima Sandstone occur north and south of the River Benue. Water occurs mostly underwater table condition. Sometimes, some clay beds confined it.

In the Lau Sub-Basin of the Upper Benue Basin, the Dukul. Sekule, Jcssu, and Numanha Formations consist mainly of clays, shales and other argillaceous materials. Groundwater occurrence in these formations is limited and therefore described as aquiclude.

The Keri-Keri Formation outcrops both in the Upper Benue Basin and the Chad Basin. This formation is a sequence of fine grained sandstones, clays, and silts with some thin coal bands. Despite the looseness and coarseness of the formation, this apparently, highly permeable sandstone formation is known to be unpredictable. Much of the arenaceous beds are dry with little or no water at the top beds.

The Middle Benue Basin is subdivided into the following formations: Interbedded sandstones of the Awe Formation, the sandstones of the Makurdi Formation and Ezeaku Formation, sandstones of the Agwu Formation, basal sandstones of the Lafia Formation. The Asu River Group underlies the Awe Formation and is essentially an aquitard or aquiclude. The overlying Awe Formation comprises flaggy, whitish, medium to coarse, sometimes 
calcareous sandstones, with interbedded shales, thin limestone and clays from which issue brines. Towards the base the sandstones become finer grained and more micaceous. However, the water from the aquiferous beds is contaminated by the brines from the interbedded shales. The shales confined the aquifers and present artesian to subartesian situation. The Markudi Formation like the Bima comprises highly indurated sandstones which are almost impermeable in some places. Where they are fractured or less indurated, they are more permeable and present a good aquifer. The Keana and the Ezeaku Formation in the Middle Benue Basin appear most important aquifers. The Keana Sandstones usefulness as a potential groundwater reservoir depends on its secondary permeability derived from weathering and fracturing.

The Agwu Formation in the Middle Benue consists of grey bedded shales with occasional sandstones and limestone beds. The sandstone beds are usually coarse, very permeable and water bearing but often limited in thickness and lateral extent, hence reducing the groundwater potential. The overlying clay beds confined the lenticular sandy aquifers.

The basal sandstones of the Lafia Formation comprised essentially of sandstones. This formation overlies the Agwu Formation. It ranges in thickness from about 10 to $150 \mathrm{~m}$ in Lafia area and much thicker towards the southwest of the town. The formation is highly permeable and gives rise to several springs at its contact with the less permeable Agwu Formation.

\subsection{The Niger Basin}

The Niger Basin is divided into the Upper and the Lower Niger Basin. The Upper Niger Basin consists of the broad valley of the River Niger, from the confluence of the River Niger and Benue to the northwest boarder of Benin Republic. Two main patches of the sedimentary rocks occur, one to the northwest and the other to the east. The northwest part of the sedimentary basin is underlain by the Illo Formation. They are considered to be the lateral equivalent of the Gundumi Formation of the Sokoto Basin [15].

The Illo Formation is reported to be about $213 \mathrm{~m}$ thick [15]. The aquifer occur only as lenses within a predominantly clayey formation. The eastern sedimentary area is underlain, essentially, by the Nupe Sandstone. In some restricted areas along the course of River Niger, alluvial deposits occur. The Nupe Sandstones consist of slightly cemented fine to coarse-grained sandstones and siltstones with interbedded thin beds of carbonaceous shale and clays. The Nupe Sandstones appear to lie directly on the basement. The fine texture of the sands and the rapid alternation of sands with clay, mudstones and silt, tend to reduce the groundwater potential of the Nupe Sandstones.
In the Kainji area, a similar sequence of rocks consisting of fine to coarse sandstones and conglomerates overlies the basement [15].

The Lower Niger Basin is the southern half of the River Niger. It falls within a broad northwest-southwest depression, through which the River Niger meanders into the Benue Valley. The Patti Formation with a maximum thickness of about $100 \mathrm{~m}$ of fine to medium sandstones, clay and carbonaceous silty to lithic ironstones, is equivalent to the Mamu Formation east of the Niger and thins out northward where it overlies $300 \mathrm{~m}$ of Lokoja Sandstone. The formation, which appears to underlie the Patti Formation, to the north of Lokoja in the Abaji area is more promising as an aquifer than the overlying Patti Formation.

\section{METHODOLOGY}

\subsection{Field Sampling and Data Collection}

Data were compiled from existing literature as well as from analysis. Most data obtained from early literature had no coordinates, and hence coordinates for such data were generated using the Google Earth map. Also, Water samples from the major aquifer units in different parts of northern Nigeria were collected from different drinking water sources following closely the methods recommended by APHA.

\subsection{Laboratory Analysis}

Analysis of the water samples were carried out at the Activation and Acme Laboratories, Canada. At the Activation Laboratories, the ICPOES was used to determine the major and trace elements and the Ion Chromatography was used to determine the anions including fluoride. At the Acme Laboratories, the Combine ICPAES/ICPMS was used to determine the major cations, Ion Chromatography for the anion and the Ion Selective Electrode was used to determine fluoride ion.

\subsection{Statistical Analysis}

The SPSS version 10 for windows was employed to obtain the ranges of the data using the descriptive statistical methods.

\subsection{Results and Discussion}

Range of fluoride values in drinking water sources from different aquifer units is displayed in Table 1. The proposed background value determined in this study is displayed in Figure 2 together with the World Health Organisation Upper and Lower limit for fluoride consumption in water. Fluoride concentration image map of northern Nigeria is shown in Figure 3. 
Table 1. Range of fluoride values in water from different aquifer units of northern Nigeria gathered from literature and analysis.

\begin{tabular}{ccc}
\hline Aquifer units & Range of fluoride in $\mathrm{mg} / \mathrm{L}$ & No of samples \\
\hline Basement & $0.03-10.30$ & 233 \\
Sedimentary & $0.00-5.00$ & 328 \\
Younger Granites & $0.00-0.89$ & 27 \\
Volcanic & $0.00-0.78$ & 39 \\
\hline
\end{tabular}

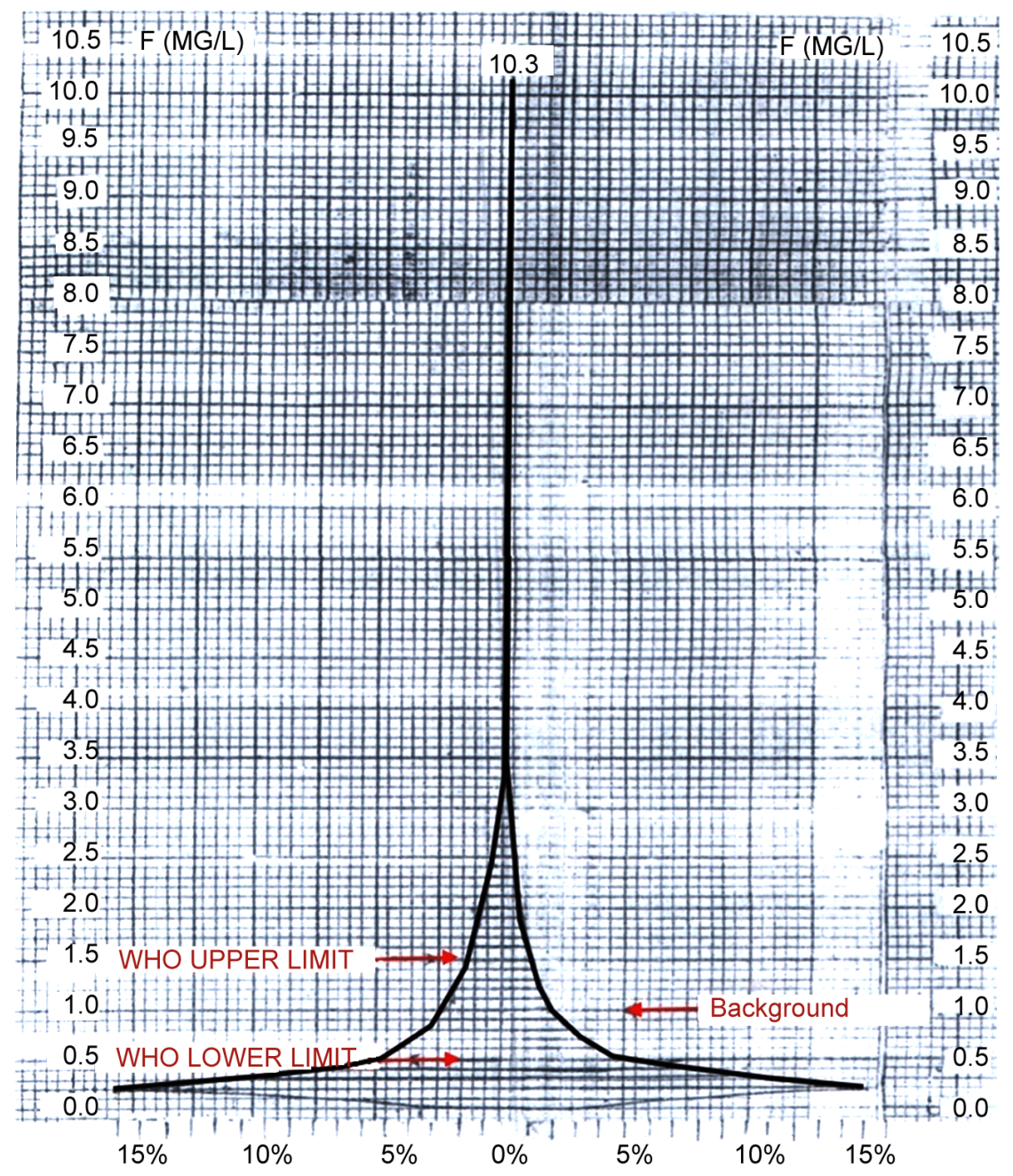

Figure 2. Frequency of fluoride concentration in water of northern Nigeria.

\section{FLUORIDE DISTRIBUTION IN THE AQUIFER UNITS}

\subsection{Basement Aquifers}

Fluoride concentration in the basement aquifers ranges from 0.03 to $10.30 \mathrm{mg} / \mathrm{L}$. Forty seven percent of waters in the basement aquifer fall below the proposed background level of $1.00 \mathrm{mg} / \mathrm{L}$ and fifty three percent are above it. Fluoride concentration of 10.30, 7.72 and 8.0 $\mathrm{mg} / \mathrm{L}$ were recorded in a well at Langtang and springs at Furzi and Dorong in the north central basement complex by $[16,10]$. In the northeast basement aquifers, values of $7.00 \mathrm{mg} / \mathrm{L}$ were recorded in a borehole and a well each at Dass by [17] and 3.14, 2.97 and $2.25 \mathrm{mg} / \mathrm{L}$ in a spring, hand dug well and a borehole at Dilchidima, Dzuma and Ngalbi [16]. Biliri, Kaltungo and Shongwom are other areas with high values of fluoride concentration. A Hand dug well at Biliri and Kaltungo have $4.00 \mathrm{mg} / \mathrm{L}$ of fluoride each in their waters and at Shongwom, $2.36 \mathrm{mg} / \mathrm{L}$ of fluoride was recorded in a hand dug well [9]. Values of 2.22 and $2.52 \mathrm{mg} / \mathrm{L}$ of fluoride concentration in the northwest basement aquifers were recorded in a hand 


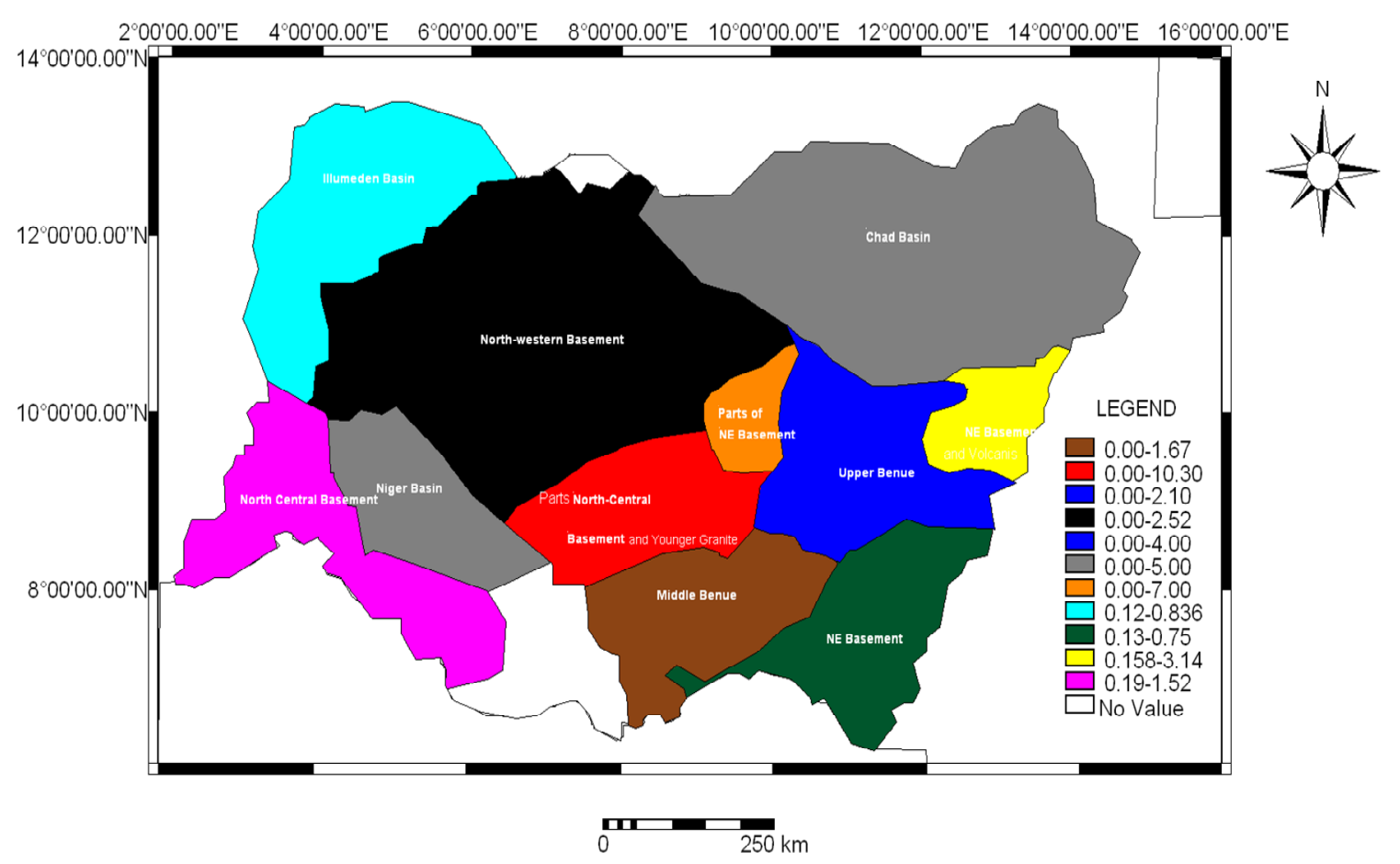

Figure 3. Fluoride image map of Northern Nigeria.

dug well at Shawo and Barkin Lamba [16]. Low values of fluoride concentration $(0.03-0.08 \mathrm{mg} / \mathrm{L})$ were recorded in the meta-sedimentary aquifers in the northwest basement areas at Maru in all the water sources [16].

\subsection{Sedimentary Aquifers}

The sedimentary aquifers have fluoride concentration in the range of $0.00-5.00 \mathrm{mg} / \mathrm{L}$. Eighty nine percent of the waters have fluoride concentration below the proposed $1.00 \mathrm{mg} / \mathrm{L}$ background value and eleven percent above it. Three boreholes each at Maiduguri, tapping water from both the Upper Zone and Lower Zone Aquifer in the Chad Basin have only traces of fluoride as reported by [18]. Value of $0.2-5.00 \mathrm{mg} / \mathrm{L}$ of fluoride were recorded in the middle Zone Aquifer by [19]. However, sixty nine water samples analysed by [18] recorded fluoride ranging from $0.00-0.80 \mathrm{mg} / \mathrm{L}$. At Gombe, in the Upper Benue Basin, fluoride concentration values of 2.10, $2.50 \mathrm{mg} / \mathrm{L}$ in two dug wells in the northeast zone have been recorded [20,21]. Fluoride concentration value of $1.67 \mathrm{mg} / \mathrm{L}$ was recorded in a borehole at Keana in the Middle Benue Basin [16]. The highest value of fluoride concentration recorded in the northwest sedimentary aquifers is $0.836 \mathrm{mg} / \mathrm{L}$ in a hand dug well [21].

\subsection{Younger Granite Aquifers}

The Younger Granites Aquifers have values in the range of 0.00 to $0.89 \mathrm{mg} / \mathrm{L}$. Values of $0.64,0.86$ and $0.89 \mathrm{mg} / \mathrm{L}[16,22,23]$ of fluoride concentration were re- corded in a borehole at Kufang, a mining pond and a hand dug well at Shen. One hundred percent of the samples have values lower than the background value of 1.00 $\mathrm{mg} / \mathrm{L}$. Results of Laboratory ananlysis by [13] reported fluoride in the range of 0.00 to $0.07 \mathrm{mg} / \mathrm{L}$.

\subsection{Volcanic Aquifers}

Fluoride concentration in the Volcanic Aquifer ranges from 0.00 to 0.78 . A hand-dug well at Biu in the northeast Volcanic Province has the highest value of 0.78 $\mathrm{mg} / \mathrm{L}$ [23]. In the north central Volcanic Province, highest value of $0.59 \mathrm{mg} / \mathrm{L}$ [24] of fluoride was recorded in a borehole at Panyam. One hundred percent of the waters in the volcanic aquifers have fluoride concentration below the proposed background values of $1.00 \mathrm{mg} / \mathrm{L}$.

\subsection{Fluoride Concentration in Waters and Effects on Health in Northern Nigeria}

Groundwater fluoride distribution expressed in image plot is displayed in Figure 2. The WHO maximum guideline limit of $1.5 \mathrm{mg} / \mathrm{L}$ for fluoride in drinking water has been adopted as the upper interval levels and 0.5 $\mathrm{mg} / \mathrm{L}$ as the lower limit. Fluoride level required to prevent tooth decay have been reported as ranging from 0.5 to $1.5 \mathrm{mg} / \mathrm{L}$ [1].

With over forty percent of the water points in the basement aquifers having fluoride content, above the 1.5 $\mathrm{mg} / \mathrm{L}$ World Health Organisation recommended limits, it is clear that excessive fluoride is being consumed in 
drinking water at; Dzuma, Dilchidima (Plate 1), Ngalbi, Biliri, Shogwom, Kaltungo, Dass, Shawo and Barkin Lamba in the northeast and northwest basement complex respectively. In the north central basement areas, Furzi (Plate 2), Dorong and Langtang in Plateau State recording values of 7.00, 7.72, 8.0 and $10.3 \mathrm{mg} / \mathrm{L}$ in water are consuming five times more than [1] recommended limits. Inhabitants of these areas show clear manifestation of dental fluorosis as seen in the plates. Although cases of stiff and brittle bones/joints, deformities in knees; crippling skeletal fluorosis and hip fracture in women, and other associated high fluoride groundwater diseases have not yet been reported, such diseases may not be lacking in these areas. In Langtang Town [11], reported clear manifestation of genu valgum (Bowing of

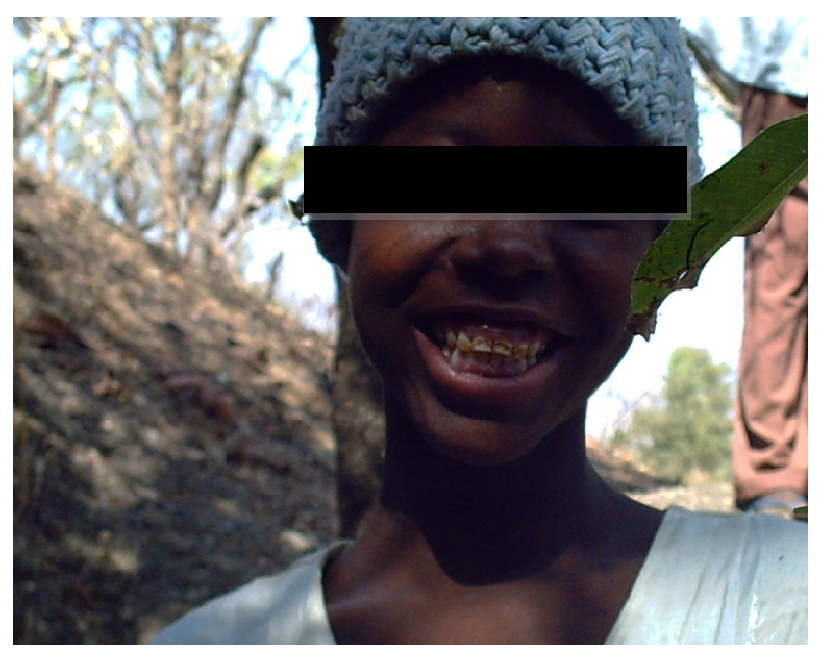

Plate 1. A 12 year old girl showing dental fluorosis at Dilchidima village in the northeast basement areas. Fluoride content in water consumed is $3.14 \mathrm{mg} / \mathrm{L}$. Coordinates: $10^{\circ} 09.428^{\prime} \mathrm{N}$ and $12^{\circ} 57.731^{\prime} \mathrm{E}$.

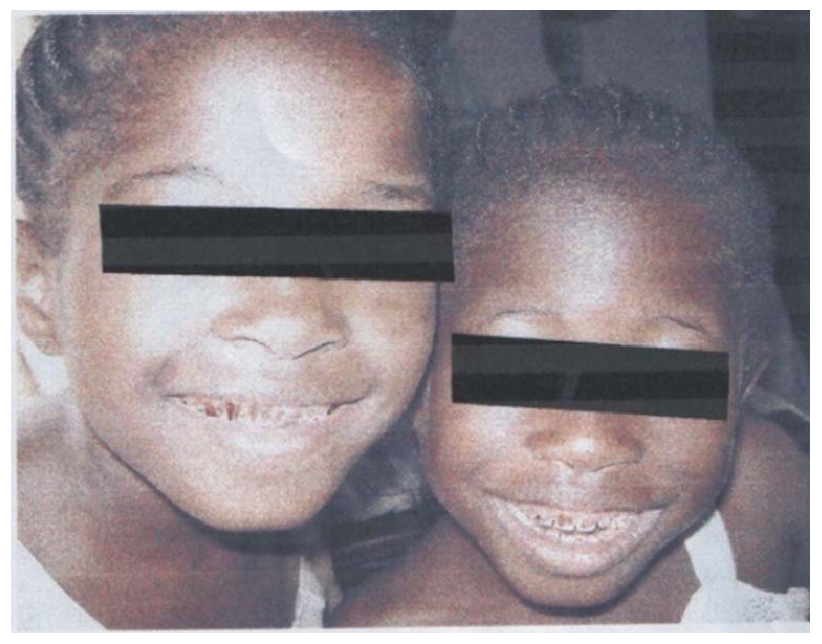

Plate 2. Girls of ages (8 and 10) years old are showing dental fluorosis at Furzi, Jos east-north central Basement areas. Fluoride content consumed in groundwater is $7.2 \mathrm{mg} / \mathrm{L}$. legs) in school aged children.

In the sedimentary areas seventy nine percent of the water points have fluoride values below the $0.5 \mathrm{mg} / \mathrm{L}$ recommended for dental caries prevention. Thirteen percent are within the WHO optimal limit of 0.5 - $1.5 \mathrm{mg} / \mathrm{L}$ and eight percent are above the WHO upper limit of 1.5 $\mathrm{mg} / \mathrm{L}$.

In the Younger Granites Province and the volcanic environment eighty two and ninety four percent of their water points have fluoride concentration lower than the $0.5 \mathrm{mg} / \mathrm{L}$ recommended for dental caries prevention. Cases of dental caries have not yet been reported, in these areas. However, [25] observed that cases of dental loss are common in the inhabitants of Panyam area especially in the age group between 40 - 50 years. Inferences from the data obtained in this study show that, low consumption of fluoride in the Younger Granites and volcanic environments may result in the development of dental caries.

\section{SUMMARY AND CONCLUSIONS}

Study on fluoride concentration in the natural water systems of the major aquifer units of northern Nigeria, shows that the basement aquifer have the highest level of fluoride concentration, followed by the sedimentary aquifer, the Younger Granites aquifer and the volcanic aquifers have the lowest.

Areas identified with high levels of fluoride in the basement aquifers above the World Health Organisation Upper Limit of $1.5 \mathrm{mg} / \mathrm{L}$ in the northeast basement aquifer are: Dzuma, Ngalbi, Udin, Dilchidima, Biliri, Kaltungo and Shogwom and Dass In the sedimentary lithologies are Maiduguri, Mafa, Logomani, Mobbar, Ngala in Borno State. The north central basement lithologies have areas like Dorong, Furzi, in Jos East Local Government Area and Langtang Town in Langtang. Pakoro town in Niger State is the only area identified in the north central sedimentary aquifer. Barkin Lamba and Shawo are areas identified in the northwest basement aquifer. No anomalously high groundwater fluoride has been identified in the sedimentary lithologies of the northwest.

Areas identified as high fluoride groundwater provinces, shows that inhabitants of these areas have symptoms of dental fluorosis among various age groups. Earlier study done in Lantang Town has established positive correlation between consumption of high groundwater fluoride and genu valgum (bowing of legs) among school children.

The Younger Granites and the volcanic province have been delineated as dental caries prone areas owing to the low levels of fluoride in their waters.

\section{ACKNOWLEDGEMENTS}

We wish to acknowledge the management; Centre for Oral Health 
Jos, for making some of the data available to us for the success of this work. Also, to the various libraries where some of the data were compiled and to all whose work has been consulted, we wish to say that, you have been duly referenced.

\section{REFERENCES}

[1] WHO (2004) Guidelines for drinking water quality. 3rd Edition, World Health Organization, Geneva.

[2] Zheng, B.S., Wu, D.S., Wang, B.B., Liu, X.J. and Wang, M.S. (2005) The main geochemical process leading to the prevalent of endemic fluorosis. China Journal of Endemics, 24, 468-471.

[3] Yang, L.S., Peterson, P.J., Williams, W.P., Wang, W., Li, R.B. and Tan, J.A. (2003) Developing environmental health indicators as policy tools for endemic fluorosis management in the People Republic of China. Environmental Geochemistry and Health, 25, 281-295.

[4] Yang, J.Y. (2000) The study on dynamic characteristics of fluoride migration in unsaturated soil. Journal of Taiyuan University of Technology, 31, 107-109.

[5] Dissanayake, C.B. (1991) The fluoride problem in ground waters of Sri Lanka. Environmental problems and health. International Journal and Environmental Studies, 19, 195. doi:10.1080/00207238208709990

[6] Hussain, J., Sharma, K.C. and Hussain, I. (2004) Fluoride in the groundwaters of Rajastan. Indian Journal Environmental Health, 7, 84-87.

[7] Richard, J.R., Martin, A.A.S. and Antonio, L. (2006) Metal speciation and its role in bioaccessibility and bioavailability. Nita and Martin ed Medical Mineralogy and Geochemistry, 64, 15-21.

[8] Fung, K., Zhang, Z. and Wong, M. (1999) Fluoride contents in tea and soils from tea plantation into tea liquor during infusion. Environmental Pollution, 104, 197-412. doi:10.1016/S0269-7491(98)00187-0

[9] Dibal, H.U. and Lar, U.A. (2005) Preliminary survey of fluoride concentrations in the groundwaters of Kaltungo Town and Environs. Gombe State. Northeastern Nigeria: Water quality and health implications. Journal of Environmental Sciences, 17, 736-742.

[10] Lar, U.A., Dibal, H.U., Daspan, R. and Jaryum, S.W. (2007) Fluoride occurrence in the surface and groundwater of Fobur area of Jos East LGA of Plateau States. Journal of Environmental Sciences II, 2, 99-105.

[11] Wongdem, J.G., Aderinokun, G.A., Sridhar, M.R. and Selkur, S. (2002) Prevalence and distribution pattern of enamel fluorosis in Langtang Town. African Journal of Medical Science, Fluoride, 35, 120-135.
[12] Offodile, M.E. (1976) Ground water study and development in Nigeria. Mecon Geology and Engineering Ltd., Jos, 453.

[13] Schoeneich, K. and Mbonu, W.C. (1991) Excursion guide book: On the geology of the Jos Plateau and the Yankari Game reserve. The Nigerian Mining and Geosciences Society 27th Annual Conference and 30th Anniversary Celebrations, Jos.

[14] Oteze. G.E. (1976) The hydrogeology of northwestern Nigeria Basin. In: Kogbe, C.A., Ed., Geology of Nigeria, Elizabethan Publishing Company, Lagos.

[15] Adeleye, D.R. (1972) Stratigraphy and sedimentation of the Upper Cretaceous Strata around Bida. In: Offodile, M.E., Ed., Ground Water Study and Development in Nigeria, Mecon Geology and Engineering Ltd., Jos.

[16] Dibal, H.U. (2012) Fluoride concentration in some parts of northern Nigeria. PhD Dissertation, Department of Geology, Ahmadu Bello University Zaria.

[17] Izeze, E. (2005) Geology and fluoride concentration in the groundwaters of Dass area. Unpublished BSc Project, Department of Geology and Mining, University of Jos.

[18] Barber, W. (1965) Pressure water in the Chad Formation of Bornu and Dikwa Emirate, Northeast Nigeria. Geological Survey of Nigeria Bulletin, 35, 62-68.

[19] Oteze, G.E. and Ayegbusi, M.S. (2002) The continental terminal aquifer in Northeast Nigeria. Journal of the Nigerian Association of Hydrogeologist, 13, 62-69.

[20] Thompson, J.H. (1958) The geology and hydrogeology of Gombe, Bauchi Province. Records of the Geology Survey of Nigeria, 46-56.

[21] ICOH (2003-2004) Fluoride content of waters in some parts of Nigeria. International Center for Oral Health Reports, Jos.

[22] Chibuzor, E.B. (2011) Geology and water quality of some ponds around Gazon Village and environs, Plateau State. Unpublished BSLT Project, Department of Geology and Mining, University of Jos.

[23] Chilota, E.R. (2011) Geology and trace elements content in abandoned mined ponds waters of Bargada Area, Plateau State. Unpublished BSLT Project, Department of Geology and Mining, University of Jos.

[24] Dibal, H.U. (2000) Fluctuation and quality of groundwater in the Biu area. Unpublished MSc Thesis, Department of Geology, University of Maiduguri.

[25] Guskit, R.B. (2010) Major and trace element distribution in natural waters and soils in Panyam Volcanic ProvinceHealth Implication. Unpublished MSc Thesis, Department of Geology and Mining, University of Jos. 